\title{
Hospitality entrepreneurship: A link in the career chain
}

\author{
Siets Andringa, Jill Poulston, and Tomas Pernecky \\ Auckland University of Technology, Auckland, New Zealand
}

This will be published as:

Andringa, S., Poulston, J., \& Pernecky, T. (2016), 'Hospitality entrepreneurship: A journey, not a destination', International Journal of Contemporary Hospitality Management, 28(4). doi:10.1108/IJCHM-05-2014-0247

Please consult the final published version if citing. Text may differ slightly.

\begin{abstract}
The objective of this study is to investigate the motivational factors behind the transition of successful hospitality entrepreneurs in New Zealand, back into paid employment. Sixteen interviewees were recruited using the snowball technique and their stories examined using a narrative analysis technique. Motivational factors were categorised into seven themes of family, work-life balance, health and stress, age, planned exit, stagnation, and intuition. Poor work-life balance was identified as a consistent factor in decisions to sell hospitality businesses. Although life-styles were self-imposed, they were exacerbated by the conflicting needs of family, customers, and the owners themselves, several of whom worked to exhaustion. Implications for prospective entrepreneurs include considerations of work-life balance and the true costs of hospitality business ownership. This is the first study of motivations for leaving a successful hospitality business and moving into paid employment. As research is sparse on reasons for this transition, this study provides an understanding of this phenomenon, and insights into the extraordinary challenges of hospitality entrepreneurship in New Zealand.
\end{abstract}

Keywords: Employment, Entrepreneurship, Hospitality, Motivation, New Zealand, Worklife balance

\section{Introduction}

Hospitality entrepreneurship is a pivotal factor in the development and growth of many national economies (Hospitality Standards Institute, 2012), and in New Zealand, a significant proportion of hospitality businesses are small owner-operated outlets (Restaurant Association of New Zealand, 2008, Statistics New Zealand, 2010). Therefore, understanding the nature of, and challenges faced by hospitality entrepreneurs is an important issue for researchers, as well as current and future entrepreneurs, financial institutions, local authorities, and government.

Every year, many hospitality entrepreneurs close down their businesses. Small businesses in the United States (USA) have the highest percentage of closure $(25.2 \%)$ in their first year, followed by 17.9 percent and 15 percent respectively in the second and third years (Headd and Kirchhoff, 2009). Although there is a wealth of research on successful (e.g. Walker and Brown, 2004, Camillo et al., 2008) and unsuccessful (Watson and Everett, 1996, Parsa et al., 2005, Parsa et al., 2011) entrepreneurship in the industry, some closures are not caused by bankruptcy or retirement, but by the owners' decisions to return to paid work (Watson and Everett, 1996). Little is known about these entrepreneurial 'drop-outs', who for unknown reasons, sell successful businesses and return to paid employment. Their change of roles has prompted this examination of factors influencing hospitality entrepreneurs to leave ownership roles even when their businesses are doing well. 
This article reports on an exploratory study of qualitative data collected through open-ended questions, examining why hospitality entrepreneurs choose to return to paid employment, and results provide an important understanding of the many factors influencing entrepreneurs to sell or close their businesses.

\section{Literature review}

\section{Entrepreneurship as a career}

Hospitality entrepreneurship is a popular career choice, with three quarters of culinary arts students in the USA showing interest in having their own hospitality business (George, 1990a, 1990b). Furthermore, half of Generation Y population (nominally those born between 1978 and 1988) prefer setting up a business to working for others, reflecting the independent and self-reliant nature of this generation (Martin, 2005). For many hospitality employees therefore, running their own business is likely to be an attractive goal, and perceived as the pinnacle of a hospitality career.

Nascent entrepreneurs are pulled into business ownership in good economic climates by perceptions of opportunities for personal gain, or pushed by employment instability (Gilad and Levine, 1986, Korotov et al., 2011). Whereas guaranteed employment has a detrimental impact on the formation of new businesses, job dissatisfaction and career setbacks can push people into developing new businesses. As entrepreneurship is 'the pursuit of opportunity beyond the resources currently controlled by the pursuer' (Korotov et al., 2011, p. 128), those who seek a career in entrepreneurship are likely to be motivated by a desire for a better way of life. A career in entrepreneurship requires resilience (Hedner et al., 2011) and those who succeed enjoy the independence, freedom, job satisfaction, and money that business ownership can offer (Alstete, 2008). However, long hours, stress, and the responsibilities and risks of business ownership are reported to be the disadvantages of an entrepreneurial career (Alstete, 2008)

\section{Entrepreneurship in New Zealand}

Entrepreneurship is particularly popular in New Zealand, where an overwhelming majority (97\%) of businesses have fewer than 20 employees, and are mostly $(90 \%)$ staffed solely by the owners (Ministry of Innovation Business and Employment, 2014). These small businesses dominate the local hospitality sector, and are characterised by a high rate of business start-ups and closures (Inland Revenue Department, 2011). The most commonly cited reason for embarking on small business ownership in hospitality is lifestyle change, and seasonal work and high staff turnover are considered likely contributors to many closures (Ministry of Innovation Business and Employment, 2014).

\section{Influences on closures}

Research identifies a variety of factors for high start-up and closure rates. External factors include the requirement for relatively low capital investment in small hospitality businesses, less dependency on specialist knowledge, and relatively low qualification barriers (Lockyer and Morrison, 1999), but this comparatively easy access to hospitality business ownership can cause problems for those lacking experience or business acumen. The importance of size, location, competitive density, and chain affiliation for restaurants is therefore acknowledged as influential on closures (Parsa et al., 2011), as are internal factors such as the owners' characteristics (Parsa et al., 2005) and stress (Wallace, 2003).

\section{Restaurant closures}

Independent restaurants have an ownership turnover rate of almost 60 percent in the first three years of operation (Parsa et al., 2005); this study therefore focuses on those who survive 
and pass this three year turning point, concentrating on reasons for quitting other than the viability of the business. While research identifies a variety of reasons for quitting both hospitality and entrepreneurship (see Table 1), the focus has previously been on unsuccessful businesses, identifying why they failed, and therefore, why the owners sought work elsewhere. As there is no research identifying reasons for quitting a successful hospitality business, it is not yet known if motivations change when a business is successful.

Influences on exiting hospitality businesses (see Table 1) that are not influences on exiting entrepreneurship generally (e.g. anti-social hours, emotional demands, and parental influence) are linked thematically, in that they are more personal in nature, and focus on entrepreneurs' personal responses to their environment.

Table 1: Reasons for exiting entrepreneurship and exiting hospitality

\begin{tabular}{|l|l|l|}
\hline Reason & Authors & Location \\
\hline Entrepreneurship & & \\
\hline Education & Hendry et al. (1995) & USA \\
\hline & Parsa et al. (2005) & USA \\
\hline Family & Kirkwood and Tootell (2008) & NZ \\
\hline & Kirkwood and Walton (2009) & NZ \\
\hline Health & Greenglass (1991) & Canada \\
\hline & Drnovsek et al. (2010) & Sweden \\
\hline Life-cycle stage & Parsa et al. (2005) & USA \\
\hline $\begin{array}{l}\text { Location, size } \\
\text { chain affiliation }\end{array}$ & Parsa et al. (2011) & USA \\
\hline Retirement & Taylor (1999) & UK \\
\hline & Watson and Everett (1996) & Australia \\
\hline Work-life balance & Kirkwood (2004) & NZ \\
\hline & Walker and Brown (2004) & Australia \\
\hline Jennings and McDougald (2007) & USA \\
\hline & Kirkwood and Tootell (2008) & NZ \\
\hline Hospitality & $\begin{array}{l}\text { Ministry of Innovation Business and } \\
\text { Employment (2014) }\end{array}$ & NZ \\
\hline Anti-social hours & Hwang and Lockwood (2006) & UK \\
\hline Education & Nolan (2002) & Ireland \\
\hline & Parsa et al. (2005) & USA \\
\hline & Avcikurt et al. (2010) & Turkey \\
\hline $\begin{array}{l}\text { Emotional } \\
\text { demands }\end{array}$ & Lo and Lamm (2005) & NZ \\
\hline Life-cycle stage & Parsa et al. (2005) & USA \\
\hline Parental influence & Wong and Liu (2010) & USA \\
\hline Social stigma & Wildes (2005) & China \\
\hline Stress & Wallace (2003) & USA \\
\hline & Lo and Lamm (2005) & Australia \\
\hline Work-life balance & Camillo et al. (2008) & Ministry of Innovation Business and \\
\hline & Employment (2014) & USA \\
\hline
\end{tabular}




\section{Stress and lifestyle issues}

Education, life-cycle stage and work-life balance are common reasons for leaving both hospitality and entrepreneurship, and are personal issues that imply an on-going search for a better way of life. It is therefore interesting to note that the search for an improved lifestyle is also identified in New Zealand Government research (Ministry of Innovation Business and Employment, 2014) as a primary motivation for embarking on business ownership.

\section{Motivation}

Motivation explains the causes of activity (Ryan and Deci, 2000) and is the driving force by which people achieve goals (King, 1997), and motivations for entering and exiting entrepreneurship vary. According to Locke and Baum (2007), a major reason for entering entrepreneurship is the stimulus of an entrepreneurial attitude, but such a person also needs to be motivated to start and retain a business and become an important factor in that process. The desire to create, build, or buy a business is the first step towards entrepreneurial activity; this desire or idea forms part of the motivation, but is usually supported by specific goals that the activity hopes to produce. Entrepreneurial motivations identified by Feldman and Bolino (2000) are varied, and include both positive aspects of the change to business ownership, as well as some undesirable features of the life being left behind:

Greater control over my life; use my skills and abilities, live where/how I like; greater ability to be creative, like the challenge; had some good ideas for a business; earn lots of money; gain more respect/recognition; reached a career plateau in my last job; avoid workplace discrimination; retired from my last job.

Measures of success for an entrepreneur are therefore not limited to financial rewards, but include personal goals such as status and respect in a community, personal ambitions, and the social benefits of autonomy (Morrison et al., 1999). This is in accordance with Herzberg's (1959) theory, which states that the things that motivate are intrinsic factors such as the achievement of personal goals and status, whereas extrinsic factors such as financial reward merely limit satisfaction when they are not achieved. The desire to improve one's lifestyle is therefore an important intrinsic motivator for entering entrepreneurship, and a persistent theme in research on small hospitality businesses (e.g. Morrison, 2002, Goulding et al., 2004, Morrison and Teixeira, 2004, Thyne and Laws, 2004, Tucker and Lynch, 2004, Morrison, 2006). Getting away from city life, avoiding the 'rat race' (Morrison, 2002), being able to live in a preferred location (Morrison et al., 2008), balancing work/life and having family quality time (Getz et al., 2004), are all identified as lifestyle motivations for entering entrepreneurship.

Lifestyle changes are important influences on entering and leaving entrepreneurship, and are arguably common reasons for most deliberate changes to personal circumstances. While it is therefore likely that the desire for a better life is also the underlying motivation for quitting a successful hospitality business for paid employment, this is yet to be established.

\section{Research approach}

Rather than establishing a hypothesis, which has the potential to limit the range of answers to the research question, this study takes an exploratory approach to discovering the reasons for exiting entrepreneurship. A qualitative methodology was therefore selected, being more suitable for research projects where the variables are not known, and where the main goal is to explore (Creswell, 2012). In-depth interviews allowed participants to determine their own responses to open-ended questions, and helped develop a depth of understanding by adjusting questions in response to participants' answers rather than having them fixed. Conversations 
were digitally recorded, transcribed, and subsequently copied on to a portable media player for repeated review, and NVivo9 software helped sort data into themes.

Narrative analysis was used to understand and examine each participant's story. Life stories provide a sound basis for understanding entrepreneurial motivations (Johansson, 2004), so it was reasoned that this would also apply to ex-entrepreneurs. Furthermore, as narratives have a linear structure it was possible for interviewees to tell their story in chronological order, emphasising significant points as they went, and reflecting on these. Narrative analysis describes accounts that relate to episodes in someone's life and the relationships between them (Bryman and Bell, 2007), so although the focus of this study was on reasons for leaving entrepreneurship, participants were also asked to narrate their reasons for entering selfemployment, and their experiences of business ownership. Their reflections on their employment experience after business ownership also helped understand the connections between exiting and the context in which the transition occurred, enabling the study to identify a multitude of motivational factors.

Themes were identified by bringing components or fragments of ideas or experiences together that would have been meaningless if viewed in isolation (see Myers, 2009). NVivo9 was used to collect quotes of each theme together, and 'combine efficient management of non-numerical, unstructured data with powerful processes of indexing, searching, and theorizing (Creswell, 2012, p. 243). Codes were then generated from salient quotes (e.g. 'the family pets were unhappy'), and checked by further listening to the recordings, to search for further and similar codes from other participants, to ensure none was missed. This analysis provided up to 38 motivations for one participant, and averaged nearly 17 motivational factors per participant. The codes were then sorted into sub-themes based on the outcomes of the problems stated (e.g. too busy to look after family and personal matters) which were then collapsed into seven broad themes to enable a clear presentation of results.

Snowball sampling was used to identify participants, because although ex-entrepreneurs are not necessarily visible in the community, they often have contact with one another through their own networks. Interviews were stopped after 16 participants, as at that stage, data were sufficiently rich to generate a range of themes to explain reasons for leaving selfemployment. In a New Zealand study of motivations for entering sustainable business ownership, Kirkwood and Walton (2009) showed data saturation after 14 cases; although it was expected that this study would reach saturation around this point, this did not occur as explained in the conclusion.

The sample group was controlled to capture equal gender voices, as women are underrepresented in hospitality research literature ( $\mathrm{Li}, 2008)$, as well as in entrepreneurship research (Mallon and Cohen, 2001), and also because $60 \%$ of New Zealand hospitality employees are women (Whiteford and Nolan, 2007, Neill et al., 2011). Participants were interviewed in Auckland, New Zealand's largest city; two married couples and one pair of business partners were co-interviewed about their businesses, and all participants worked in Auckland at the time of the study.

Twelve participants were born in New Zealand and four were from the United Kingdom (UK). One of the British participants had owned multiple businesses, including one that was overseas, but all other participants' businesses were in New Zealand. All had extensive hospitality experience and knowledge, and not just practical experience, and many had culinary qualifications, particularly the chef-owners; one had 30 years' experience as an employee when she started her first hospitality enterprise. The youngest participants started their businesses in their mid-twenties, while the oldest were nearly 50 when they started self-employment. The 16 participants worked in 27 businesses in total, as some had 
several operations (see Table 2). The most common roles for owners were Front of House (FOH) Manager and Chef Manager. Pseudonyms are used to protect participants' identities.

Table 2: Participant profiles

\begin{tabular}{|c|c|c|c|c|}
\hline Name & Business partner & Role & Business types & $\begin{array}{l}\text { Years in } \\
\text { business }\end{array}$ \\
\hline Anna & Spouse & $\begin{array}{l}\text { Product developer } \\
\text { and manager }\end{array}$ & Frozen yoghurt shop & 5 \\
\hline Bruce & Fiancé & FOH manager & Restaurant/bar & 5 \\
\hline Carlos & Business partner & Chef manager & $\begin{array}{l}\text { Bistro-café and } \\
5 \text { food-court outlets }\end{array}$ & 11 \\
\hline Dora & Spouse & FOH manager & $\begin{array}{l}\text { Restaurant and } \\
\text { consultancy }\end{array}$ & 3.5 \\
\hline Emma & Chef + silent partner & FOH manager & French bistro and bar & 5 \\
\hline Fred & None & Chef manager & Out catering & 5 \\
\hline Gary & Spouse & Chef manager & Restaurants (2) & 8 \\
\hline Hank & Business partner & Chef manager & Restaurant//bistro bar & 4 \\
\hline Ian & Spouse & Chef manager & Restaurant & 6 \\
\hline John & Spouse & FOH manager & Restaurant & 4 \\
\hline Keith & Subleased kitchen & Chef manager & Café & 4 \\
\hline Lea & Silent partner/friend & Chef manager & Café & 6 \\
\hline Maria & $\begin{array}{l}\text { Spouse, None, Bus. partner } \\
\text { Spouse } \\
\text { Fiancé } \\
\text { Fiancé }\end{array}$ & FOH manager & \begin{tabular}{|l|}
3 hotels \\
1 motel \\
1 management rights \\
1 restaurant \\
\end{tabular} & 11 \\
\hline Nina & Spouse +1 partner & FOH manager & Restaurant & 6 \\
\hline Olga & $\begin{array}{l}\text { Fiancé }+3 \text { business } \\
\text { partners }\end{array}$ & FOH manager & Restaurant/bar & 4.5 \\
\hline Pippa & Partner & FOH manager & Restaurant & 3.5 \\
\hline
\end{tabular}

Through multiple business ownerships, two participants had accrued 11 years selfemployment, whereas the shortest self-employment was three and a half years. The average business ownership for women was 5.6 years, compared to 5.9 years for men, the average self-employment was 5.7 years, and some form of partnership was generally involved, such as with a spouse, fiancé or business partner(s). All had sold their businesses between 1997 and 2011, except one who still owned the business and worked part-time in it while also working in full-time employment elsewhere. All had been employed since selling their business, or were already employed before they sold. None mentioned any difficulty in finding paid employment; to the contrary, most had several positions to choose from and had been asked by businesses, colleagues or agents if they were available for work.

\section{Findings}

Results are discussed under the seven themes of family, work-life balance, health and stress, age, planned exit, stagnation, and intuition. Themes were not derived from existing research, but identified through familiarisation with the data from repetitive listening to the recordings. Although some motivations (e.g. 'family' and 'health and stress') were mentioned repeatedly, themes were not selected according to frequency, and some had not been identified in prior studies (e.g. 'planned exit' and 'intuition'). Some were easily identified because of their transparent content, while others were more difficult because they emerged 
from less explicit content. Reasons for exiting self-employment and returning to paid work are presented below by theme.

\section{Family demands}

It was anticipated that family demands would involve dependent children, but participants talked of partners or spouses, aging or ailing parents, children, grandchildren and even children they wanted to have. The difficulties of balancing family and business demands were complex.

We did breakfast, lunch and dinner, six days a week, and on the seventh day we were - the chef was doing the ordering and I was doing the books, by hand. And we were absolutely exhausted. And during that time my father died, but I still had to - we had functions (Pippa).

It's difficult in a hotel with a child you know, because - well they're living in it. When they go to their friend's place and they go to have dinner there and they ask him what he likes for dinner and he'll go 'I'll have a pot of chips' or 'I'll have a seafood chowder thank you'. I think we've got a son who doesn't know what a normal lifestyle is (Maria).

It was really just family commitments. I had a young child. I had to choose between two babies literally. I had to give my baby [the business] away and I had to get over it. It broke my heart (Anna).

Eight participants had children while owning a business, and at the time of the interview 11 had children. Many considered hospitality workplaces unsuitable environments for raising children, which influenced their decisions to return to paid employment.

Poor work-life balance

Some participants sought a better work-life balance; work-life problems arose because they were unable to withdraw from their business, either because of financial pressures or a sense of obligation to their customers to be constantly visible.

What I found was, the business was me. So, if someone booked a dinner they wanted me there to cook the dinner (Fred).

We got tired, really tired. We came home about 3.30. The chef was sleeping on the floor in the kitchen, just to get a little break in between. I just got worn out really, and the chef did not want to sell initially, but he knew how tired I was (Pippa).

Quality of life is the main reason we sold actually. There is no life. I lived in a bubble for five years. I worked six days and nights for five years and I had no life. And my home wasn't home; it was just a - it was like a railway station really. That's where I came. I dropped things off, went to bed, had breakfast in the morning, picked things up and left, and I did that for five years. And yeah, anyone who thinks there is something romantic about owning a restaurant needs to... you know (Emma).

Although participants had differing values and aspirations, it became apparent that all had worked hard on their business with long hours and few holidays.

Poor health and stress

Business pressure negatively affected the health of some participants and increased their stress, which established a cycle of fatigue leading to reduced productivity, decreased customer satisfaction, and with more effort to overcome the problems, more fatigue. Although owners therefore worked longer to maintain productivity, the reduced recuperation time cumulatively increased their fatigue, and the overwhelming time commitment required 
to manage their business was evident.

I actually ran myself down to the ground and I've spent a year and a half doing nothing. I was just a mess; it was almost like a breakdown. I couldn't take any stimulus on. I couldn't give anything. I was just completely drained. It wasn't an illness, it was just a total giving. I hadn't learned to divorce my love for people from my business sense. There was no boundary; I couldn't find the boundary, I wanted to look after everyone (Nina).

I was absolutely mentally and physically drained (Lea).

Life is so short, and quality of life is so important, and health and wellbeing are so important. And a restaurant is no place for health and wellbeing, and it's no place for quality of life (Emma).

Several felt that they and their business were one, and that the business was not the same if they were not present.

Age

The decision to exit entrepreneurship related to age, reflected in life cycle stage and the desire to have children, as well as the physical and mental need for increased recuperation from a demanding occupation. Participants did not consider themselves old, although some were over 50 years old at the time of selling.

I was not tired, but I wasn't 28 anymore [over 50]. Twenty-four seven, it was getting a little bit hard (Carlos).

I must have been mid-thirties then and it really started to take its toll. I got to it reasonably late. I must have been 29 or 30 when we bought it and so it was really getting hard (Bruce).

\section{Planned exit}

For two participants, planned exits were related to age, as they were nearly 50 when they started their business. Several believed it was better to buy at a low price, develop the business, then sell for a profit, rather than work hard and extract daily profit from turnover, whereas others had set themselves a goal or challenge, and once this was achieved, they felt happy to sell.

We had a ten-year lease on the property, and my intention was always to sell probably at the three and a half to four year mark, to realise what we had put into it (John).

Our plan was when we bought it, we would do three to five [years]. And at three we were still enjoying ourselves (Dora).

Because of their industry experience, participants knew hospitality ownership would not allow for a regular working schedule, although several expected to retain their business for a time before fatigue overcame them.

\section{Stagnation}

Small business owners often work alone or in a small team, and some experienced this solitary role as isolating, because autonomy also meant having no one to bounce ideas off. The consequent lack of knowledge exchange resulted in feelings of becoming staid and uninspired, and this poor personal development motivated some to return to paid employment and interaction with peers, which they perceived as stimulating.

The best thing about being here [in paid employment] is, it doesn't matter where you are, you're still learning, but I've learned a lot more. I'm learning from my colleagues, and 
I'm learning from colleagues who specialise in different areas. And being your own boss, you don't get that. You're the top man really, and you're learning by default perhaps, chasing your tail. But here, there's always someone you can go to (Carl).

A restaurant is just a vehicle and that vehicle for me does not take me anywhere. I've gone as far as I can in there (Nina).

For some, the decreasing passion and excitement for their business was a signal to move on.

\section{Intuition}

This was the most difficult theme to identify and name, as comments relating to this theme were subjective and not coded initially, having not been part of an obvious pattern. However, there was an identifiable theme relating to what participants called 'karma', or 'spiritual', and several participants described aspects of their business or life that were outside their control in subjective terms. Although comments relating to serendipity, karma or synchronicity were difficult to interpret, a sense of precognition, being spiritually drained, and spontaneous recognition of an opportunity were also part of this theme; some attributed finding their restaurants to interesting coincidences.

We'd just taken this big road trip looking at restaurants. Gosh, it's interesting when I tell you. So we decided that was the type of place that we would like. And we came back to Auckland to think about how we would go about doing it, when that very restaurant came up out on the market. It is one of those funny things. We picked up the paper and there it was for sale, and so one thing led to another (Bruce).

However, Bruce later felt this restaurant had drained him spiritually:

Spiritually I could not afford it anymore. You got to the end of it. It wasn't fun anymore

Gary and John talked of karma in relation to their life choices.

The four years for us seemed to be the point where we would sell. We sold the first restaurant, the second restaurant. I'm a big believer in karma, so it's just-you can't go backwards - it's not something you can change (Gary).

I think the time had come for me to say enough... no one ever knows, but the time was right. It really wasn't planned. It just fell into place. It's always been part of my life. It's my karma (Carlos).

Fred and Gary both talked of synchronicity or cycles in relation to how long they stayed in their jobs and retained their operations, and while there was little evidence of distinct cyclical periods, fortuitous coincidences were interpreted as synchronous.

\section{Discussion}

Each theme identified in the foregoing section is discussed in detail in this section, and significant aspects of the theme compared to those in the literature.

Family demands

Although several motivations were mentioned, ten participants identified family issues as the main reason for selling their business, and several considered a hospitality workplace an inappropriate environment for raising children. Interestingly, some had initiated selfemployment for family reasons, consistent with the findings of Morrison and Teixeira (2004), who identified family as a motivational factor for both entering and exiting entrepreneurship. Kirkwood and Tootell (2008) found that although time flexibility can appear to be an advantage of entrepreneurship, particularly for women, this is somewhat of a myth, as several felt bound to their business, with little flexibility. Their findings are confirmed in this study, 
whose participants found it difficult to balance business and family responsibilities such as children, grandchildren, spouse/partner, and ailing and aging parents.

\section{Work-life balance}

Although some participants wanted time with children and grandchildren, work-life balance was a major issue, and not limited to family demands, as some wanted time with friends, while others wanted to care for a dying relative or have a holiday. While it is common to seek self-employment to pursue a better work-life balance (e.g. Morrison and Teixeira, 2004), it is also important to develop a business concept that satisfies personal and family goals.

In a study of failed businesses, Camillo et al. (2008) concluded that ignoring the balance between family, personal needs and work, will likely result in a failed business venture. Although participants in this study were successful, they had no respite from their responsibilities, and some thought their business could not operate at optimum capacity without them. Not surprisingly, several struggled to find a balance between work, life, home, and family.

\section{Health and stress}

Health problems such as high blood pressure, varicose veins and elevated cholesterol levels were all reported; long hours, the pressure to maintain financial viability, easy access to alcohol, and staff issues, raised participants' stress levels and affected their health. Drnovsek et al. (2010) found a strong relationship between personal well-being and business performance, and observed entrepreneurs make both emotion-based and problem-based decisions. Whereas an emotion-based decision is reactive, suppressing engagement, and incorporating people into the problem, a problem-based strategy is proactive, defining the problem, and generating and evaluating solutions before making a decision. Drnovsek et al. found that emotion-based strategies were commonly used for problems beyond an entrepreneur's control; these are associated with increased levels of depression, anxiety and insomnia (Greenglass, 1991) and affect well-being generally. The intensity of engagement with participants' businesses in this study suggests they were unable to control their businesses without being physically present, and therefore, emotion-based strategies were common, contributing to health problems.

Emotional labour, a characteristic of service work (Guerrier and Deery, 1998, Seymour, 2000, Pizam, 2004), is linked to increased job stress and decreased satisfaction, and can undermine a worker's well-being generally (Pugliesi, 1999). Because emotional labour and soft skills such as 'looking good' and 'sounding right' (Nickson et al., 2005) are expected by customers, and arguably, suppliers, front-line workers are expected to develop a rapport with customers (Gardner and Wood, 1991), and need to work hard to consistently meet expectations. The costs of this effort should not be underestimated; producing a genuine smile and pleasant temperament may be difficult for owners who are tired and in need of sleep and time out. Results of this study suggest that as service workers and business managers, hospitality entrepreneurs are likely to suffer the negative consequences associated with emotional labour and emotion-based decision-making.

Age

Both men and women felt their 'body clock' ticking, and expressed the desire to start a family before becoming too old. Chronological age incurs a gradual loss of physical energy (Böttiger, 1973), and Masuda (2010) found that a common reason for leaving entrepreneurship was illness and/or advancing age. While participants in this study might not have considered themselves old, some felt self-employment was becoming increasingly difficult, and paid employment seemed easier, less time consuming and less demanding 
generally. Bosma et al. (2008), Taylor (1999), and Watson and Everett (1996) identified retirement as a common motivator for quitting business ownership, which explains why entrepreneurs are generally young (Curran and Blackburn, 2001, Kautonen, 2008). However, in this study, none of the participants who indicated that age influenced their transition, had reached the retirement age of 65 , indicating they were not ready to stop working, but just to stop owning a business.

\section{(Accelerated) planned exit}

Several participants had a target (financial or otherwise), and once this was achieved they were happy to sell, although their planned exit was often brought forward due to fatigue. Participants all had prior hospitality experience and knew that business ownership would entail long hours and irregular shifts, so emotional demands (Lo and Lamm, 2005) and antisocial hours (Hwang and Lockwood, 2006) of hospitality work was anticipated. However, fatigue overcame some, accelerating their planned exit.

\section{Stagnation}

Some participants felt their growth and advancement during self-employment had stagnated, which motivated them to return to paid employment. Herzberg's (1968) two-factor theory explains that some workplace factors satisfy employees (motivation factors) while others lead to dissatisfaction (hygiene factors). The lack of motivating factors such as opportunities for advancement and personal growth therefore explains why participants left their businesses to return to paid work, where these could be more readily found. Those citing a lack of personal development as a reason for returning to paid employment, wanted the stimulation of interacting with colleagues, learning new skills, and updating others.

Herzberg's motivation factors are aspects of work that satisfy not just employees, but also the self-employed. In a survey of people working from home as well as those working in a business location, no differences were found in the intrinsic and extrinsic needs of the two groups (Green, 2009), suggesting that these are universal needs. Therefore, opportunities for development, growth, advancement and recognition are not only important to employees, but also to hospitality entrepreneurs, who may exit their entrepreneurial roles in order to have these needs met.

\section{Intuition}

Some participants felt that entrepreneurship had been an important part of their life because business ownership was part of their career progression, creating a sense that entrepreneurship had served a purpose they had not recognised when they first embarked on their ownership journey. Several therefore described their decisions and opportunities as good karma, or serendipity, especially in terms of timing around business start-up and sale. Goleman (2006, p. 54) called intuitive signals such as these, 'gut feelings', and suggested that many decisions are guided by these rather than through rational processes. He further stated that an array of choices can be pared down to a more manageable decision matrix by paying attention to intuitive signals and gut feelings (Goleman, 2006). In this study, some entrepreneurs were alert to these intuitive signals, and used them to guide decisions such as leaving their business.

\section{Conclusion}

The aim of this study was to identify themes linking the transition from hospitality entrepreneurship to paid employment. Although the study discussed seven major themes of family, work-life imbalance, health and stress, age, planned exit, stagnation, and intuition, findings indicated that work-life balance underpinned the various sub-themes, such as family, 
health and stress, age, planned exit, and stagnation. If work-life balance had been better managed, most of the reasons for leaving entrepreneurship would not have arisen, and participants may well have still been self-employed. It is also interesting to note that although age and planned exit do not necessarily connote work-life balance issues, interview data revealed direct connections between these.

Each experience was unique, from initial entry into self-employment with individual personal perceptions, dispositions, skills, life-cycle stages and aspirations, to the business itself, its development, and the circumstances around leaving it. Although a combination of factors such as personal environment, personal goals and beliefs, social and economic factors, and the external environment all influenced reasons for leaving a successful business, several participants mentioned poor work-life balance as the main reason for returning to paid employment.

Journeys were experienced as personal endeavours of making dreams come true, and striving for growth, and learning, and although seven themes were explored in this study, they were not discrete, and others emerged that were not discussed. Analysis of results concentrated on the key personal issues under each theme, and problems such as lack of business skills (financial, marketing, human resources and systems), religion, racism, natural disasters, unhappy pets, and co-dependent relationships with other businesses were also raised, and could be explored in future research. So many reasons were provided for quitting a successful business, it is posited that data saturation is not achievable in a study of this nature, because individual entrepreneurs are unique, and will therefore present an infinite combination of reasons for their actions. This is considered a significant finding, and is in conflict with a common goal of qualitative research, to seek data saturation before completing data collection. This study demonstrates that this is not always possible and not necessarily required, as a rich variety of data can also generate significant findings.

The discovery that participants were ultimately forced to recognise the importance of the work-life balance issues that drove them out of entrepreneurship agrees with literature identifying work-life balance issues as challenging in both hospitality work (Pienaar and Willemse, 2008, Deery and Jago, 2009, Lewis and Gruyere, 2010) and entrepreneurship generally (Jennings and McDougald, 2007, Kirkwood and Tootell, 2008). Furthermore, a satisfying family and social life is important to health and well-being, so if fatigue and stress interfere with family and social events, this will result in discontent and therefore more stress and fatigue until circumstances are changed.

Hospitality business ownership appeared more like a black hole in the ground than the pinnacle of a mountain that participants may have once dreamed of. Their businesses drew all their energy and time, and a real effort seemed to be needed to climb out of the hole and improve their circumstances. Businesses were described as a baby, a roller-coaster ride, a trap, and a vehicle that does not go anywhere, and one participant talked of 'unplugging' from the business, connoting a connection that had to be severed to secure freedom. Their business became part of them, their identity, and arguably, their ego, and some were so focused on their operation, that personal interests and relationships with family and friends were neglected. They underestimated the need for time out and continued working until they could work no longer, at which time they had no option but to sell. Those who focused on financial goals had fewer problems selling, and some started another business before returning to paid employment. These participants seemed to have a more realistic business approach based on financial return, rather than feelings of responsibility for customers.

Although some participants were adamant they did not want to be self-employed again, they were nevertheless passionate about business ownership as they reflected on their experiences, 
even though the energy and focus needed for successful entrepreneurship had been too intense and pervasive for them to continue indefinitely. Several felt they had been pulled away from self-employment and the change to paid work was a positive move, viewing selfemployment as just another step in their career. For them, selling their operation was an important life decision, after which they were able to reorganise their life-style to one of a paid employee. Many in this study emerged from business ownership with an increased awareness of the need for a balanced approach to life and work, so current and nascent hospitality entrepreneurs can learn from their experiences by reading the accounts of those who have gone before them. This may encourage them to stay in hospitality entrepreneurship longer, and maintain consistency of business ownership; high turnover of not just paid employees but also of owners, threatens to take valuable skills and knowledge away from the industry. This study finds that while the high turnover of small hospitality businesses (Inland Revenue Department, 2011) can be attributed to an almost endless variety of factors, the very desire to take control of one's life (Korotov et al., 2011) and have a better lifestyle as an entrepreneur (Ministry of Innovation Business and Employment, 2014), is also what lures many out again, back into paid employment.

\section{Implications and recommendations}

If business owners envisage a lengthy period of entrepreneurship, implications for practice suggest they will need to consider work-life balance issues carefully, and think about conflicting demands on their time and energy that may result in fatigue, or the inability to attend to important matters such as sitting with a dying relative. Some participants experienced extreme exhaustion, and addressed this by changing to paid employment. Their resilience and ability to recover from the stress of long hours and hard work had diminished to the point of no return, and could not be regained.

\section{Implications for research}

The outcomes of this research are valuable by providing a different context for considering the move from business ownership to paid employment, and identify a range of legitimate reasons for this to happen. Although the poor work-life balance of an entrepreneur appears self-inflicted, expectations of self, partner, family, community and customers all contribute to a difficult balancing act that will affect the likely tenure of ownership. It would therefore be useful to test the comparative importance of themes identified in this study, so it can serve as a basis for establishing a greater degree of accuracy on reasons for leaving entrepreneurial hospitality businesses.

As poor work-life balance is identified as the most likely motivator for leaving selfemployment, it was initially considered recommending that work-life balance skills be developed in small business management courses, thus equipping prospective entrepreneurs with the skills to work more effectively. However, as owner-managers frequently lack basic management skills and formal education (Pizam and Holcomb, 2008), attempts to create better work-life balance for entrepreneurs through education may be futile. Similarly, some suffered from poor health and stress, and although Drnovsek et al. (2010) noted that rational problem-solving techniques can be developed through training, participants bemoaned the lack of time and energy available for personal development. Recommendations from this study are therefore necessarily more focussed on implications for research, than for practice.

Considerations of work-life balance and the true costs of business ownership were not generally recognised prior to buying a business. Although some had planned their exit before embarking on business ownership, they had been unrealistic about the time involved, and the impact of stress caused by emotional labour, the need to survive, and hard work, and the 
long hours and fatigue precluded any opportunities for personal development. Further research is therefore needed to determine if this unhappy combination of factors affects other types of entrepreneurial businesses, and if so, how business owners address these. Research is also required to determine how those who stay in hospitality businesses manage these issues, so solutions can ultimately be generated for other entrepreneurs.

It may appear a limitation of this study, that data on education levels were not collected, as poor education may have contributed to participants' stress and work-life balance problems, if they lacked the knowledge needed for successful business operation (in a recent study of small hospitality businesses in Auckland, four of the five participants did not have a degree (Rosalin et al., 2016), which was considered to negatively affect their ability to operate effectively). However, the purpose of the study was to record motivations identified by entrepreneurs for exiting their businesses, rather than generate conclusions from demographic data. Some interviewees mentioned their education, commenting that hospitality entrepreneurship lacked the status expectations they had of their bachelor's degree; one felt that studying marketing might have made them more successful, and another thought having financial skills would have increased their business success and therefore reduced their stress.

Demographic data were collected at the start of each interview on the location, type and size of the business, and type of customers served, to provide a background for questions, and to 'warm up' participants. However, unless interviewees identified any of these as a motivation to leave, they remained as background information only and were not added to the list of motivations. However, future qualitatively-oriented studies could utilise demographic data to generate additional themes. While this study was qualitative in nature, it is possible that new findings could be revealed in future studies by examining the social, cultural and geographic contexts of participants, using quantitative data to identify large-scale generic patterns across larger populations. There are different methods available for researchers to conceptualise, organise and cluster motivational factors, so the distinctions between intrinsic and extrinsic motivational factors, push and pull factors, and personal and external factors offered in this study, can therefore be helpful in designing future research.

Continued research is required on the work-life balance of entrepreneurs, and possible influences on this, such as education, age, and gender. Although Eddleston and Powell's (2012) study of entrepreneurs showed significant differences between male and female workfamily balance, they attributed this to the different perspectives of men and women. It would therefore be useful to examine different attitudes to and satisfaction with work-life balance. Finally, it would be helpful to know the characteristics of entrepreneurs who seek mentoring or support, and to determine the effects of this on work-life balance and success, financial or otherwise.

\section{References}

Alstete, J. W., (2008), "Aspects of entrepreneurial success", Journal of Small Business and Enterprise Development, Vol. 15, No. 3, pp. 584-594.

Avcikurt, C., Altay, H. \& Ilban, M. O., (2010), "Critical success factors for small hotel businesses in Turkey: An exploratory study", Cornell Hospitality Quarterly, Vol. 52, No. 2, pp. 153-164.

Bosma, N., Jones, K., Autio, E. \& Levie, J., (2008), Global Entrepreneurship Monitor: 2007 Executive Report, Babson College and London Business School, London, UK.

Böttiger, L. E., (1973), "Regular decline in physical working capacity with age", British Medical Journal, Vol. 3, No. 5874, pp. 270-271.

Bryman, A. \& Bell, E., (2007), Business Research Methods, Oxford University Press, Oxford, NY. 
Camillo, A. A., Connolly, D. J. \& Kim, W. G., (2008), "Success and failure in northern California: Critical success factors for independent restaurants", Cornell Hospitality Quarterly, Vol. 49, No. 4, pp. 364-380.

Creswell, J., (2012), Educational Research: Planning, conducting, and evaluating quantitative and qualitative research, Pearson Education, Boston, MA.

Curran, J. \& Blackburn, R. A., (2001), "Older people and the enterprise society: Age and selfemployment propensities", Work, Employment \& Society, Vol. 15, No. 4, pp. 889-902.

Deery, M. \& Jago, L., (2009), "A framework for work-life balance practices: Addressing the needs of the tourism industry", Tourism and Hospitality Research, Vol. 9, No. 2, pp. 97-108.

Drnovsek, M., Ortqvist, D. \& Wincent, J., (2010), "The effectiveness of coping strategies used by entrepreneurs and their impact on personal well-being and venture performance", Sveuciliste u Rijeci, Vol. 28, No. 2, pp. 193-220.

Eddleston, K. A. \& Powell, G. N., (2012), "Nurturing entrepreneurs' work-family balance: A gendered perspective", Entrepreneurship Theory and Practice, Vol. 36, No. 3, pp. 513-541.

Feldman, D. C. \& Bolino, M. C., (2000), "Career patterns of the self-employed: Career motivations and career outcomes", Journal of Small Business Management, Vol. 38, No. 3, pp. 53-67.

Gardner, K. \& Wood, R. C., (1991), "Theatricality in food service work", International Journal of Hospitality Management, Vol. 10, No. 3, pp. 267-278.

George, R. T., (1990a), "Culinary arts students: An empirical study of career and ownership orientation", Journal of Hospitality \& Tourism Research, Vol. 14, No. 1, pp. 11-21.

George, R. T., (1990b), "Hospitality students in two-year programs: A comparison study of career orientation", Journal of Hospitality \& Tourism Research, Vol. 14, No. 2, pp. 209-216.

Getz, D., Carlsen, J. \& Morrison, A., (2004), The family business in tourism and hospitality, CABI Publishing, Oxfordshire, UK.

Gilad, B. \& Levine, P., (1986), "A behavioral model of entrepreneurial supply", Journal of Small Business Management, Vol. 24, No. 4, pp. 45-53.

Goleman, D., (2006), Emotional intelligence: Why it can matter more that IQ, Bantam Dell, New York, NY.

Goulding, P. J., Baum, T. G. \& Morrison, A. J., (2004), "Seasonal trading and lifestyle motivation: Experiences of small tourism businesses in Scotland", Journal of Quality Assurance in Hospitality \& Tourism, Vol. 5, No. 2, pp. 209-238.

Green, J. W., (2009), 'Exploring the needs of teleworkers using Herzberg's two factor theory', $\mathrm{PhD}$ thesis, Northcentral University, Ann Arbor, MI.

Greenglass, E. R., (1991), "The relationship between stress and coping among type As", Journal of social behavior and personality, Vol. 6, No. 7, pp. 361-371.

Guerrier, Y. \& Deery, M., (1998), "Research in hospitality human resource management and organizational behaviour", Hospitality Management, Vol. 17, No. 2, pp. 145-160.

Headd, B. \& Kirchhoff, B., (2009), "The growth, decline and survival of small businesses: An exploratory study of life cycles", Journal of Small Business Management, Vol. 47, No. 4, pp. 531-550.

Hedner, T., Abouzeedan, A. \& Klofsten, M., (2011), "Entrepreneurial resilience", Annals of Innovation \& Entrepreneurship, Vol. 2, No. 1, pp. 1-4.

Hendry, C., Arthur, M. \& Jones, A. M., (1995), Strategy through people: Adaption and learning in the small-medium enterprise, Routledge, London, UK.

Herzberg, F., (1959), The motivation to work, Wiley and Sons, New York, NY.

Herzberg, F., (1968), Work and the nature of man, Granada Publishing, London, UK. 
Hospitality Standards Institute, (2012), "Career in hospitality", available at: http://www.hsi.co.nz/career-in-hospitality (accessed 1 May 2015).

Hwang, L. J. \& Lockwood, A., (2006), "Understanding the challenges of implementing best practices in hospitality and tourism SMEs", Benchmarking: An International Journal, Vol. 13, No. 3, pp. 337-354.

Inland Revenue Department, (2011), "The hidden economy", available at: http://www.ird.govt.nz/resources/a/f/af041480431ela7c866ce75d5f60e4be/complianc e-hidden-economy.pdf, (accessed 1 May 2015).

Jennings, J. E. \& Mcdougald, M. S., (2007), "Work-family interface experiences and coping strategies: Implications for entrepreneurship research and practice", Academy of Management Review, Vol. 32, No. 3, pp. 747-760.

Johansson, A. W., (2004), "Narrating the entrepreneur", International Small Business Journal, Vol. 22, No. 3, pp. 273-293.

Kautonen, T., (2008), "Understanding the older entrepreneur: Comparing Third Age and Prime Age entrepreneurs in Finland", International Journal of Business Science and Applied Management, Vol. 3, No. 3, pp. 1-13.

King, A. S., (1997), "The crescendo effect in career motivation", Career Development International, Vol. 2, No. 6, pp. 293-301.

Kirkwood, J., (2004), 'One size doesn't fit all: Gender differences in motivations for becoming an entrepreneur', $\mathrm{PhD}$ thesis, University of Otago, Dundein, New Zealand.

Kirkwood, J. \& Tootell, B., (2008), "Is entrepreneurship the answer to achieving work-family balance?", Journal of Management \& Organization, Vol. 14, No. 3, pp. 285-302.

Kirkwood, J. \& Walton, S., (2009), "What motivates ecopreneurs to start businesses?", International Journal of Entrepreneurial Behaviour \& Research, Vol. 16, No. 3, pp. 204-228.

Korotov, K., Khapova, S. N. \& Arthur, M. B., (2011), "Career entrepreneurship", Organizational Dynamics, Vol. 40, No. 2, pp. 127-135.

Lewis, R. A. \& Gruyere, L. R., (2010), "Work-life balance in hospitality: Experiences from a Geneva-based hotel", International Journal of Management and Information Systems, Vol. 14, No. 5, pp. 99-106.

Li, L., (2008), "A review of entrepreneurship research published in the hospitality and tourism management journals", Tourism Management, Vol. 29, No. 5, pp. 1013-1022.

Lo, K. \& Lamm, F., (2005), "Occupational stress in the hospitality industry: An employment relations perspective", New Zealand Journal of Employment Relations, Vol. 30, No. 1, pp. 23-47.

Locke, E. A. \& Baum, R. J., (2007), "Entrepreneurial Motivation", in Baum, R. J., Frese, M. \& Baron, R., (eds.), The Psychology of Entrepreneurship, Lawrence Erlbaum Associates, Mahwah, NJ.

Lockyer, C. \& Morrison, A., (1999), The structure, characteristics and performance of the Scottish tourism industry, University of Strathclyde, Scottish Tourism Research Unit / Fraser of Allander Institute, Glasgow, UK.

Mallon, M. \& Cohen, L., (2001), "Time for a change? Women's accounts of the move from organizational careers to self-employment.", British Journal of Management, Vol. 12, No. 3, pp. 217-230.

Martin, C. A., (2005), "From high maintenance to high productivity: What managers need to know about Generation Y", Industrial and Commercial Training, Vol. 37, No. 1, pp. $39-44$.

Masuda, T., (2010), "Job changes, entrepreneurship and regional economy", International Journal of Entrepreneurship and Small Business, Vol. 10, No. 2, pp. 257-286. 
Ministry of Innovation Business and Employment, (2014), The Small Business Sector Report, New Zealand Government, Wellington, New Zealand.

Morrison, A., (2002), "Small hospitality businesses: Enduring of endangered?", Journal of Hospitality and Tourism Management, Vol. 9, No. 1, pp. 1-11.

Morrison, A., (2006), "A contextualisation of entrepreneurship", International Journal of Entrepreneurial Behaviour \& Research, Vol. 12, No. 4, pp. 192-209.

Morrison, A., Carlsen, J. \& Weber, P., "Lifestyle oriented small tourism [lost] firms and tourism destination development ", in S. Richardson, L. F., A. Patiar \& M. Ternel, (Eds), Proceedings of the 18th Annual CAUTHE Conference: Tourism and Hospitality Research, Training and Practice, 12-14 February 2008, Griffith University, Gold Coast, Queensland, Australia, pp. 1-5.

Morrison, A., Rimmington, M. \& Williams, C., (1999), Entrepreneurship in the hospitality, tourism and leisure industries, Butterworth-Heinemann, Woburn, MA.

Morrison, A. \& Teixeira, R., (2004), "Small business performance: A tourism sector focus", Journal of Small Business Management and Enterprise Development, Vol. 11, No. 2, pp. 166-173.

Myers, M. D., (2009), Qualitative research in business \& management, SAGE Publications, London, UK.

Neill, L., Williamson, D., Waldren, N. \& Bennett, R., (2011), Hospitality Report, Restaurant Association of New Zealand (RANZ) and AUT University, Auckland, New Zealand.

Nickson, D., Warhurst, C. \& Dutton, L., (2005), "The importance of attitude and appearance in the service encounter in retail and hospitality", Managing Service Quality, Vol. 15, No. 2, pp. 195-208.

Nolan, C., (2002), "Human resource development in the Irish hotel industry: The case in the small firm", Journal of European Industrial Training, Vol. 26, No. 2, pp. 88-99.

Parsa, H. G., Self, J., Sydnor-Busso, S. \& Yoon, H. J., (2011), "Why restaurants fail? Part II The impact of affiliation, location, and size on restaurant failures: Results from a survival analysis", Journal of Foodservice Business Research, Vol. 14, No. 4, pp. 360-379.

Parsa, H. G., Self, J. T., Njite, D. \& King, T., (2005), "Why restaurants fail", Cornell Hotel and Restaurant Administration Quarterly, Vol. 46, No. 3, pp. 304-379.

Pienaar, J. \& Willemse, S. A., (2008), "Burnout, engagement, coping and general health of service employees in the hospitality industry", Tourism Management, Vol. 29, No. 6, pp. 1053-1063.

Pizam, A., (2004), "Are hospitality employees equipped to hide their feelings?", International Journal of Hospitality Management, Vol. 23, No. 4, pp. 315-316.

Pizam, A. \& Holcomb, J., (2008), International dictionary of hospitality management, Butterworth-Heinemann, Oxford, UK.

Pugliesi, K., (1999), "The consequences of emotional labor: Effects on work stress, job satisfaction, and well-being", Motivations and Emotions, Vol. 23, No. 2, pp. 125-154.

Restaurant Association of New Zealand, (2008), 2008 Foodservice Facts Restaurant/foodservice Industry Annual Sales Statistics and Analysis, Auckland, New Zealand.

Rosalin, G., Poulston, J. \& Goodsir, W., (2016), "Strategy communication in family owned restaurants: Ad hoc and ad-lib", Journal of Hospitality and Tourism Administration, Vol. 17, No. 2, In press.

Ryan, R. M. \& Deci, E. L., (2000), "Intrinsic and extrinsic motivations: Classic definitions and new directions", Contemporary Educational Psychology, Vol. 25, No. 1, pp. 5467. 
Seymour, D., (2000), "Emotional labour: A comparison between fast food and traditional service work", International Journal of Hospitality Management, Vol. 19, No. 2, pp. 159-171.

Statistics New Zealand, (2010), Tourism satellite account: 2010, Statistics New Zealand, Wellington, New Zealand.

Taylor, M., (1999), "Survival of the fittest? An analysis of self-employment duration in Britain", The Economic Journal, Vol. 109, No. 454, pp. 140-155.

Thyne, M. \& Laws, E. (Eds.) (2004), Hospitality, tourism, and lifestyle concepts: Implications for quality management and customer satisfaction, The Haworth Hospitality Press, Binghamton, NY.

Tucker, H. \& Lynch, P., (2004), "Host-guest dating: The potential of improving the customer experience through host-guest psychographic matching", in Thyne, M. \& Laws, E., (Eds.), Hospitality, tourism, and lifestyle concepts: Implications for quality management and customer satisfaction, The Haworth Hospitality Press, Binghamton, NY.

Walker, E. \& Brown, A., (2004), "What success factors are important to small business owners?", International Small Business Journal, Vol. 22, No. 6, pp. 577-594.

Wallace, M., (2003), OSH implications of shiftwork and irregular hours of work: Guidelines for managing shiftwork, National Occupational Health and Safety Commission Development, Sydney, Australia.

Watson, J. \& Everett, J. E., (1996), "Do small businesses have high failure rates?", Journal of Small Business Management, Vol. 34, No. 4, pp. 45-62.

Whiteford, A. \& Nolan, A., (2007), An employment profile of the hospitality industry, Hospitality Standards Institute, Auckland, New Zealand.

Wildes, V., (2005), "Stigma in food service work: How it affects restaurant servers' intention to stay in the business or recommend a job to another", Tourism and Hospitality Research, Vol. 5, No. 3, pp. 213-233.

Wong, S. C.-K. \& Liu, G. J., (2010), "Will parental influences affect career choice?", International Journal of Contemporary Hospitality Management, Vol. 22, No. 1, pp. 82-102. 